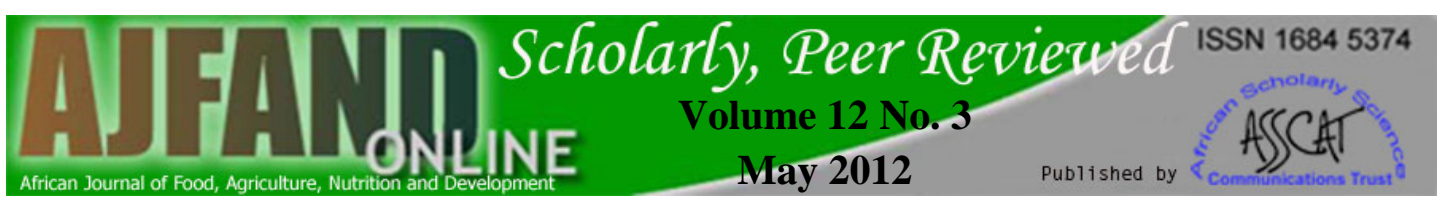

\title{
CARCASS AND SLAUGHTER TRAITS OF WEANLING PIGS FED GRADED LEVELS OF WILD SUNFLOWER (TITHONIA DIVERSIFOLIA) LEAF MEAL
}

\section{Fasuyi AO $^{*}{ }^{1}$, Ibitayo F $^{1}$ and SS Fagbuaro ${ }^{1}$}

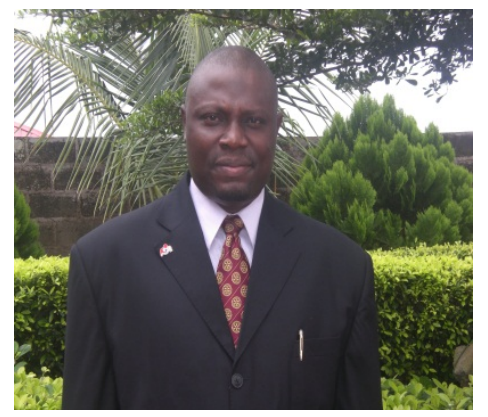

Deji Fasuyi

*Corresponding author email: dejifasuyi@yahoo.com

${ }^{1}$ Department of Animal Production and Health Sciences, Faculty of Agricultural Sciences, Ekiti State University, Ado-Ekiti, Ekiti State, Nigeria 


\section{ABSTRACT}

Growing pigs were used to assess the slaughter and carcass characteristics, organs and primal cut yields when fed diets supplemented with processed leaves of Tithonia diversifolia (wild sunflower) referred to as Tithonia diversifolia leaf meal (TDLM). A 63-day feeding trial was conducted with commercially available male Large White growing weanling pigs on four experimental diets containing $19.0 \%$ crude protein and a digestible energy value of $2997 \mathrm{kcal} / \mathrm{kg}$. Tithonia diversifolia leaf meal (TDLM) progressively replaced soybeans at $10 \%, 20 \%$ and $30 \%$ inclusion levels in diets 2, 3 and 4 , respectively. Carcass yields for pigs on 10\% TDLM were similar ( $p>0.05$ ) to the values obtained for pigs on the control diet without TDLM. Most other carcass parameters such as carcass length, chest width, trochanter width and leg length were similar ( $p>0.05)$ and variations where they existed were minimal. Slaughter traits such as live weight at slaughter, empty slaughter weight, dead weight and back fat depth were significantly better $(\mathrm{p}<0.05)$ for pigs on the control diet without TDLM inclusion at $20.2 \mathrm{~kg}, 14.6 \mathrm{~kg}, 19.1 \mathrm{~kg}$ and $0.9 \mathrm{~cm}$, respectively. These values were closely followed by the values obtained for pigs on 10\% dietary TDLM inclusion at $15.6 \mathrm{~kg}, 11.5 \mathrm{~kg}, 15.1 \mathrm{~kg}$ and $0.5 \mathrm{~cm}$ for live weight at slaughter, empty slaughter weight, dead weight and back fat depth, respectively. Poor values of empty slaughter weight, body mass index, dead weight and back fat depth were recorded for pigs on diets 3 (20\% TDLM) and 4 (30\% TDLM) ostensibly due to the low feed intake and subsequent poor weight gain and high feed conversion ratio. The above trend was repeated for offals and organs yields. However, reproductive organs were not adversely affected even at $30 \%$. Most determined experimental pig primal cuts were within moderate ranges according to literature and also similar to values obtained for pigs on experimental control diet. Conclusively, pigs on 10\% TDLM inclusion level had comparable slaughter/carcass traits, organs and primal cut yields with pigs on the control diet without TDLM and also with most reported values in existing literature. Growing pigs tolerated TDLM and in some cases surpassed the performances of pigs on conventional growing pig diets. Further research studies may be necessary to investigate the nutritional value of TDLM when more adequate processing techniques are employed to reduce its anti-nutrients.

Key words: Carcass, primal cuts, back fat 


\section{INTRODUCTION}

Pork production takes a key role in animal agriculture providing over $42 \%$ of global meat consumption [1]. Pigs performed well when fed with forage meals, and the conventional protein required for pigs could be reduced by up to $40 \%$ when the protein in the diet has the required balance of essential and non-essential amino acids subsequently referred to as the ideal protein which could be complemented by the leaf meal [2]. In addition, pigs have the capacity to consume and digest fibre, and leaves from trees, shrubs and crop plants which are relatively high in fibre [3]. Wild sunflower (Tithonia diversifolia) is a shrub in the family Asteraceae, it is an annual aggressive weed growing to a height of about $2.5 \mathrm{~m}$ and adaptable to most soils. In Nigeria, it can be found along major roads, abandoned/waste lands, water-ways and as invader of field crops in the forest savanna transition zone [4]. It can be cultivated by resource poor farmers who manipulate planting density to achieve maximum yield [5]. Little information exist on the effects of wild sunflower (Tithonia diversifolia) on the growth performance and carcass traits of poultry birds, rabbits, ruminants and growing pigs. It was reported from a previous study that weaner rabbits can tolerate the inclusion of $15 \%$ wild sunflower (Tithonia diversifolia) leaf meal in their diet, while the inclusion of up to $20 \%$ adversely affected their daily weight gain and ultimately, their final live weight [6]. The aim of this present study was to investigate the carcass qualities, slaughter traits, organ and primal cut yields of weanling pigs when fed varying levels of Tithonia diversifolia leaf meal as a replacement for conventional protein supplement. The justification of this study could be derived from the viewpoint of natural abundance and availability of Tithonia diversifolia in the forest savanna transition zones in Nigeria.

\section{MATERIALS AND METHODS}

\section{Preparation of test ingredients}

The test ingredients Tithonia diversifolia leaf meal (TDLM) was prepared by harvesting daily, the fresh and matured leaves of Tithonia diversifolia plants of different ages before flowering. The whole leaves were chopped manually using kitchen knives and then sun-dried. Sun-drying was done for 4 days, and the chopped leaves were manually turned using a rake so as to guarantee even-drying to $12-13 \%$ moisture content. Fresh and dried samples of Tithonia diversifolia leaves were taken to the laboratory for proximate and chemical analyses even before the inclusion of the dried samples into the diets [7].

\section{Experimental animals}

A total of twenty four (24) male growing pigs (about $2 \frac{1}{2}$ months old) of commercially available crosses with a mean body weight of $13.3 \pm 0.5 \mathrm{~kg}$ were used for this study. The experimental pigs were given adequate medication to prevent piglet anaemia and worms at the first week of their arrival.

\section{Standardization of experimental animals before feeding trial}

The 24 male growing pigs were all randomized into separate pens for this pre-feeding trial and each pen housed an experimental pig. They were all served a standard 
growing diet for pigs compounded with conventional feedstuffs as shown in Table 1. Daily feeding rate was $3.30 \%$ of the pigs' live weight and the pre-feeding trial was conducted for 10 days. Water was given to the pigs ad libitum throughout the period of the trial. The daily feed consumption in g/day was calculated and divided by the average daily weight gain also in g/day to obtain the feed conversion ratio means for all the pigs on the standard pig diet.

The feeding trial was carried out at the piggery unit of the Teaching and Research Farm (TRF) of the University of Ado-Ekiti for a period of 63 days. Four diets (D1, D2, D3 and D4) were formulated to contain about $19.0 \%$ crude protein and a digestible energy value of about $2997 \mathrm{kcal} / \mathrm{kg}$. The control diet was a standard growing diet for pigs compounded with conventional feed stuffs e.g. maize, soybeans, palm kernel cake (PKC), oyster shell, bone meal, brewer's dried grains (BDG), wheat offals, fish meal, salt and grower premixes. The other three diets were compounded such that Tithonia diversifolia leaf meal (TDLM) progressively replaced soybeans at $10 \%, 20 \%$ and $30 \%$ inclusion levels in diets 2,3 and 4, respectively. Daily feeding rate was $3.30 \%$ of the pigs' live weight. Water was given to the pigs ad libitum throughout the period of the experiment. The daily feed consumption in g/day was calculated and was divided by the average daily weight gain (g/day), to get the feed conversion ratio means for all the pigs on the four experimental diets.

\section{Slaughter and carcass quality traits, organs weights and primal cuts yields}

Eight pigs (two from each experimental diet) were selected for sacrifice at the end of the feeding trial, and the following parameters were measured for slaughter traits as outlined in USDA Farmer's Bulletin [8]: empty slaughter weight, blood weight, dead weight and body mass index. Offals of slaughtered pigs were separated and measured as weight of head, weight of feet from knee, length of front and back legs.

Carcass quality traits were measured in centimetre $(\mathrm{cm})$ using measuring tape except carcass yield which was calculated as percentage of live weight and outlined in USDA Farmer's Bulletin [8,9] as follows: \% carcass yield (the animal weight less head, foot, skin and gut content), carcass length (distance from end of leg to crouch), carcass width (distance from scapular to sternum), trochanter width and leg length.

Organs measured were spleen, lungs, heart, stomach, intestine, liver, kidney, bile and testes using a sensitive digital measuring scale and were expressed as percentage of carcass weight as outlined in USDA Farmer's Bulletin [8]. Primal cuts were assessed as a percentage of hot carcass weight for individual slaughtered animal, and these cuts include the half cut, quarter cut, shoulder, bacon, ham, ribs and loin eye as outlined in USDA Farmer's Bulletin [8].

\section{Statistical analysis}

The data collected in the completely randomized experimental design were subjected to statistical analysis using the Minitab Computer Software package (2005 version). 


\section{RESULTS}

\section{Carcass qualities of experimental pigs}

The carcass yields (shown on Table 1$)$ of pigs on diets 1 and 2 were similar $(p>0.05)$ at $59.3 \%$ and $59.1 \%$, respectively. These values were higher and significantly different $(\mathrm{p}<0.05)$ from the carcass yield values obtained for pigs on diets 3 and 4 which were also similar ( $>0.05$ ) at $53.9 \%$ and $51.4 \%$ for diets 3 and 4 , respectively. All experimental pigs on all diets had similar ( $>0.05$ ) average carcass length of $62.6 \mathrm{~cm}, 64.6 \mathrm{~cm}, 62.6 \mathrm{~cm}$ and $61.6 \mathrm{~cm}$ for pigs on diets $1,2,3$ and 4 , respectively. Apart from pigs on the control diet 1 which had a significantly higher $(p<0.05)$ carcass width of $28.6 \mathrm{~cm}$, other carcass width values were similar $(p>0.05)$ at $25.3 \mathrm{~cm}$, $26.3 \mathrm{~cm}$ and $26.3 \mathrm{~cm}$ for pigs on diets 2,3 and 4, respectively. Chest width values differed significantly $(\mathrm{p}<0.05)$ among pigs on all experimental diets. Pigs on diet 3 had the highest chest width value of $17.2 \mathrm{~cm}$, while pigs on diet 2 had the lowest chest width value of $14.2 \mathrm{~cm}$. The trochanter width values were similar ( $>>0.05)$ for all pigs on the four experimental diets at $21.3 \mathrm{~cm}, 20.3 \mathrm{~cm}, 20.3 \mathrm{~cm}$ and $20.3 \mathrm{~cm}$ for pigs on diets 1, 2, 3 and 4, respectively. The leg length value obtained for pigs on the control diet 1 was highest at $33.6 \mathrm{~cm}$, but similar ( $>0.05$ ) to the leg length values obtained for pigs on diets 2 and 3 at $30.6 \mathrm{~cm}$ and $30.6 \mathrm{~cm}$, respectively. Pigs on diet 4 had the lowest leg length of $29.6 \mathrm{~cm}$, but also similar ( $\mathrm{p}>0.05$ ) to values obtained for diets 2 and 3.

\section{Slaughter traits of experimental pigs}

Slaughter traits are presented in Table 2. Apart from pigs placed on the control diet 1 which had a significantly higher $(\mathrm{p}<0.05)$ live weight at slaughter value of $20.2 \mathrm{~kg}$, other live weight at slaughter values were similar ( $>0.05$ ) at $15.6 \mathrm{~kg}, 14.4 \mathrm{~kg}$, and $13.9 \mathrm{~kg}$ for pigs on diets 2, 3 and 4, respectively. Empty slaughter weight value of pigs on diet 1 was significantly higher and different $(\mathrm{p}<0.05)$ at $14.6 \mathrm{~kg}$ from those on diets 2,3 and 4 at $11.5 \mathrm{~kg}, 9.6 \mathrm{~kg}$ and $9.6 \mathrm{~kg}$, respectively. There were no significant differences $(\mathrm{p}>0.05)$ in the values of weight of intestine with offal among the pigs on diets $1,2,3$, and 4 at $4.5 \mathrm{~kg}, 3.5 \mathrm{~kg}, 4.5 \mathrm{~kg}$ and $4.4 . \mathrm{kg}$, respectively.

Numerically, pigs on diet 1 had the highest blood weight value, but there were similarities $(p>0.05)$ among the blood weight values obtained for pigs on all experimental diets at $1.1 \mathrm{~kg}, 0.6 \mathrm{~kg}, 0.7 \mathrm{~kg}$ and $0.6 \mathrm{~kg}$, for diets $1,2,3$ and 4 , respectively. Apart from pigs on diet 1 that had the significantly $(\mathrm{p}<0.05)$ highest body mass index value of 0.4 , all pigs on other experimental diets had similar ( $>0.05$ ) body mass index value of 0.3. Apart from pigs on diet 1 which had a significantly $(\mathrm{p}<0.05)$ different and highest value of dead weight at $19.1 \mathrm{~kg}$, pigs on diets 2,3 and 4 had similar ( $p>0.05$ ) dead weight values at $15.1 . \mathrm{kg}, 13.9 \mathrm{~kg}$ and $13.5 \mathrm{~kg}$, respectively.

Back fat depth value of pigs on diet 1 at $0.91 \mathrm{~cm}$ was highest and significantly different from diets 2, 3 and 4. However, pigs on diets 2 and 3 had similar $(p>0.05)$ back fat depth of $0.5 \mathrm{~cm}$ and $0.5 \mathrm{~cm}$, respectively. Pigs on diet 4 had the significantly $(\mathrm{p}<0.05)$ lowest back fat depth of $0.3 \mathrm{~cm}$. 


\section{Organs and offals yield of experimental pigs}

Organs and offal yields are shown on Table 3. The value of weight of head obtained for pigs placed on diet 1 at $2.4 \mathrm{~kg}$ was not significantly ( $>>0.05)$ different from pigs on diet 2 , and 4 at $2.0 \mathrm{~kg}$ and $1.8 \mathrm{~kg}$, respectively but significantly $(\mathrm{p}<0.05)$ different from those placed on diet 3 at $1.5 \mathrm{~kg}$ which was similar ( $>0.05$ ) to pigs on diets 2 and 4 . The values of weight of feet from knee for pigs on diets $1,2,3$ and 4 were similar $(\mathrm{p}>0.05)$ at $0.9 \mathrm{~kg}, 0.6 \mathrm{~kg}, 0.7 \mathrm{~kg}$ and $0.5 \mathrm{~kg}$, respectively.

There were significant $(\mathrm{p}<0.05)$ differences in the values obtained for the spleen weight of pigs on the four experimental diets. 25.1g was the highest mean value for diet 1 , while $19.1 \mathrm{~g}, 13.2 \mathrm{~g}$ and $17.2 \mathrm{~g}$ were mean values obtained for pigs on diets 2,3 and 4 , respectively. There were differences $(p<0.05)$ in the weights of lungs of pigs placed on diets $1,2,3$ and 4 at the values of $194.6 \mathrm{~g}, 145.6 \mathrm{~g}, 167.7 \mathrm{~g}$ and $171.7 \mathrm{~g}$, respectively. The pigs on control diet had the highest value, while those on diet 2 had the lowest value.

The pigs on diets 2, 3 and 4 had similar ( $>0.05$ ) values for the weight of heart at $59.6 \mathrm{~g}, 57.7 \mathrm{~g}$ and $61.7 \mathrm{~g}$, respectively. Only pigs on diet 1 had the significantly highest $(p<0.05)$ value of $68.6 \mathrm{~g}$. The values obtained for weight of stomach for pigs fed varying levels of TDLM in diets 1 (no TDLM inclusion), 2(10\% TDLM inclusion), $3(20 \%$ TDLM inclusion) and 4 (30\% TDLM inclusion) at $647.6 \mathrm{~g}, 482.6 \mathrm{~g}, 633.7 \mathrm{~g}$ and $539.7 \mathrm{~g}$, respectively were significantly different $(\mathrm{p}<0.05)$. Pigs on diet 1 had the highest value, followed by pigs on diets 3,4 and 2 in that order. The values obtained for the weight of intestine for pigs fed with diets $1,2,3$ and 4 were similar ( $>0.05)$ at $2.7 \mathrm{~kg}, 2.4 \mathrm{~kg}, 2.7 \mathrm{~kg}$ and $2.4 \mathrm{~kg}$, respectively.

There were significant differences in the average values of weight of liver for all the pigs on diets $1,2,3$, and 4 . Those fed with diet 1 had the highest and significantly different $(\mathrm{p}<0.05)$ value at $616.8 \mathrm{~g}$ followed by those on diets 2,3 and 4 at decreasing values of $386.0 \mathrm{~g}, 368.0 \mathrm{~g}$ and $310.5 \mathrm{~g}$, respectively.

The average value of kidney weight obtained for pigs on diet 1 was the highest at $64.8 \mathrm{~g}$ and significantly higher $(\mathrm{p}<0.05)$ than other values. Pigs on diets 3 and 4 had similar kidney weight values of 52.0g and 50.2g, respectively. Pigs on diet 2 had the lowest significantly different $(\mathrm{p}<0.05)$ value of $44.1 \mathrm{~g}$.

With the exception of pigs on the control diet 1 that had a significantly highest $(p<0.05)$ weight of bile value of $37.6 \mathrm{~g}$, other bile weight values were similar $(p>0.05)$ at $13.0 \mathrm{~g}, 11.1 \mathrm{~g}$ and $12.2 \mathrm{~g}$ for pigs on diets 2,3 and 4 , respectively. The testes weight values of the pigs placed on diets $1,2,3$ and 4 at 52.6g, 50.7g, $49.7 \mathrm{~g}$ and $48.8 \mathrm{~g}$, respectively were similar ( $\mathrm{p}>0.05)$.

The values obtained for length of front leg of pigs on diets 1 and 3 were similar $(p>0.05)$ at $15.1 \mathrm{~cm}$, but were significantly different $(\mathrm{p}<0.05)$ from those placed on diets 2 and 4 . The values for pigs on diets 2 and 4 were also similar $(\mathrm{p}>0.05)$ at $13.1 \mathrm{~cm}$ and $13.2 \mathrm{~cm}$, respectively. The values obtained for length of back legs of 
experimental pigs were similar ( $>>0.05$ ) for pigs on diets 1 and 3 at $20.1 \mathrm{~cm}$ and $19.1 \mathrm{~cm}$, respectively but significantly higher $(\mathrm{p}<0.05)$ than the similar values obtained for pigs on diets 2 and 4 at $18.1 \mathrm{~cm}$ and $18.2 \mathrm{~cm}$, respectively.

\section{Primal cut yields of experimental pigs}

Primal cut yields of pigs fed varying levels of TDLM based diets are presented on Table 4. The half cut values obtained for pigs on diets 2, 3 and 4 were statistically similar ( $>0.05$ ) at $4.7 \mathrm{~kg}, 4.1 \mathrm{~kg}$ and $3.6 \mathrm{~kg}$, respectively. However, the control diet 1 with the highest half cut values of $6.1 \mathrm{~kg}$ was also similar $(\mathrm{p}>0.05)$ to the value obtained for pigs on diet 2.

All other primal cuts yields of experimental pigs on all diets were similar ( $p>0.05)$. These parameters include quarter cut, shoulder weight, bacon weight, ham weight, ribs weight and loin eye weight. The quarter cut had the numerically highest value of $3.2 \mathrm{~kg}$ for pigs on diet 1 and lowest for both diets 3 and 4 at $2.1 \mathrm{~kg}$. The above trend was true for all other mentioned primal cut yields. Pigs on the control diet always had the highest values followed by 2, 3 and 4 in decreasing order.

\section{DISCUSSIONS}

\section{Slaughter and carcass quality traits, organs weights and primal cuts yields}

Since carcass quality traits are indication of the quality and utilization of the ration [10], it would seem that pigs on the 30\% TDLM inclusion level, poorly utilized their feed as evident by their low values on carcass yield, carcass length and leg length. Interestingly, similar values were observed for carcass length and trochanter width for all diets. High crude fibre in diet could result in poor digestibility of nutrients and this could have negative relationship with metabolisable energy (ME) and digestible energy (DE) contents of the diet, which could limit the availability of energy for muscular growth [11].

Empty slaughter weight, hot carcass weight and body mass index are functions of final body weight [10]. The poor values recorded for pigs on diets 3 (20\% TDLM) and 4 (30\% TDLM) for empty slaughter weight, body mass index, dead weight and back fat depth in this study may be due to the low feed intake, poor weight gain and high feed conversion ratio. This ultimately had a deteriorating effect on their final body weights [10]. Back fat depth range of $0.3-0.9 \mathrm{~cm}$ recorded in this study was very low compared to other report [12] at $1.92-2.75 \mathrm{~cm}$ when pigs were served rice bran diet with paddy as a replacement for maize and also smaller than another result [13] at $1.15-1.32 \mathrm{~cm}$ when pigs were served diet with biogas slurry (BGS). The observed back fat thickness reduced with increased dietary crude fibre (CF) [14, 15]. This may be an advantage particularly where lean pork is desired.

Offals yields were better for weight of head, weight of feet from knee, length of front leg and length of back leg at 20\% TDLM inclusion level. This was similar to the reported trend [13] when biogas slurry (BGS) was fed to pigs. 


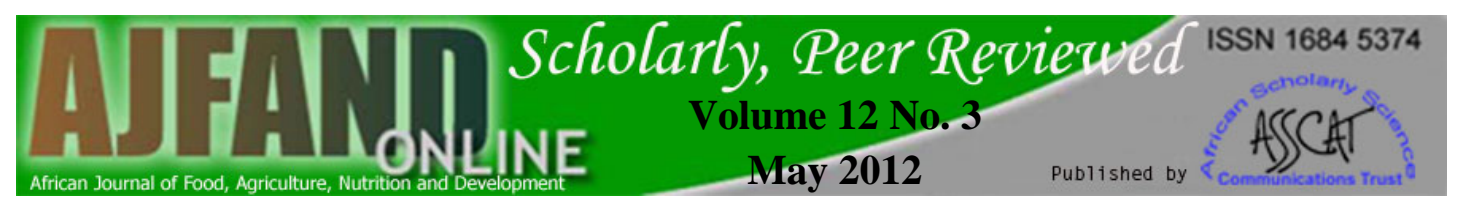

Concerning organ development, the decrease in the mean values of the weight of spleen and stomach for pigs placed on diet 3 (20\% TDLM inclusion), and the decrease in the mean value of weight of liver as the inclusion level of TDLM increased could probably be due to higher physiological activities by these organs triggered by the presence of anti-nutritional factors in Tithonia diversifolia leaf meal and their concomitant effects $[16,17]$.

The similarity observed in this study for testes weight when TDLM was included up to $30 \%$, indicated that male pigs may tolerate up to $30 \%$ TDLM without any significant adverse effect on the growth of reproductive organs. This contradicted the previous report [18] that broiler cocks may tolerate up to 10\% TDLM without any significant adverse effect on the growth of reproduction organs and also differ from the optimum level of 5\% TDLM inclusion recommended for Isa Brown cocks [19]. This is fundamental as the size and weight of testes have been reported to have a positive relationship with sperm production [18, 20-22].

The insignificant differences in the values of intestinal weight obtained on all diets is an indication that inclusion of TDLM in pigs ration up to 30\% would have no adverse effect on the development of the intestine of the animals. Although the half cut weight value of pigs on diets 3 and 4 are significantly different from those on control diet, however, the insignificant differences in the weight values of quarter cut, shoulder, bacon, ham, ribs and loin eye of pigs fed TDLM-based diet compared to those on the control diet revealed that TDLM based diets had no adverse effect on primal cut yields. This negated earlier reports [12-13] that there were significant differences in the bacon and loin weights when pigs were served with biogas slurry.

\section{CONCLUSION}

At inclusion levels above 20\% of TDLM, most carcass qualities and slaughter traits were adversely affected. Some offals yields were, however, better for pigs kept at $20 \%$ TDLM inclusion level. The decrease in the mean values of the weight of spleen and stomach for pigs placed on diet 3 (20\% TDLM inclusion), and the decrease in the mean value of weight of liver as the inclusion level of TDLM manifested the hyperfunctionally of these organs.

\section{ACKNOWLEDGEMENT}

I acknowledge the technical and laboratory assistance of Mr. Mike Oguntokun of the Animal Nutrition Laboratory, Federal university of Technology, Akure. 


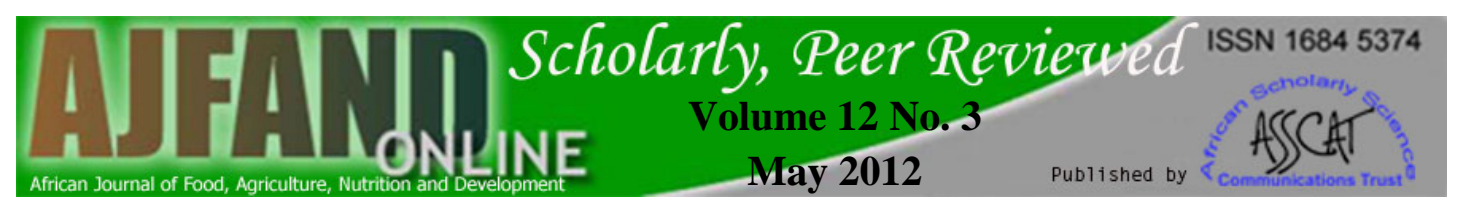

Table 1: Carcass qualities of pigs fed varying levels of TDLM based diet

\begin{tabular}{|lcccc|}
\hline \multicolumn{5}{c|}{ Diets } \\
\hline & $\mathbf{1}$ & $\mathbf{2}$ & $\mathbf{3}$ & $\mathbf{4}$ \\
\hline Parameters & \multicolumn{4}{c|}{ \% inclusion levels of TDLM } \\
\hline Carcass yield (\%) & $\mathbf{0}$ & $\mathbf{1 0}$ & $\mathbf{2 0}$ & $\mathbf{3 0}$ \\
Carcass length (cm) & $59.3^{\mathrm{a}} \pm 1.21$ & $59.1^{\mathrm{a}} \pm 1.01$ & $53.9^{\mathrm{b}} \pm 1.32$ & $51.4^{\mathrm{b}} \pm 2.01$ \\
Carcass width (cm) & $62.6^{\mathrm{a}} \pm 2.03$ & $64.6^{\mathrm{a}} \pm 3.01$ & $62.6^{\mathrm{a}} \pm 3.21$ & $61.6^{\mathrm{a}} \pm 3.23$ \\
Chest width (cm) & $28.6^{\mathrm{a}} \pm 3.24$ & $25.3^{\mathrm{b}} \pm 2.23$ & $26.3^{\mathrm{b}} \pm 2.32$ & $26.3^{\mathrm{b}} \pm 3.01$ \\
Trochanter width (cm) & $16.2^{\mathrm{a}} \pm 2.31$ & $14.2^{\mathrm{b}} \pm 2.02$ & $17.2^{\mathrm{c}} \pm 2.31$ & $15.2^{\mathrm{d}} \pm 2.31$ \\
Leg length (cm) & $21.3^{\mathrm{a}} \pm 3.01$ & $20.3^{\mathrm{a}} \pm 2.76$ & $20.3^{\mathrm{a}} \pm 2.31$ & $20.3^{\mathrm{a}} \pm 2.34$ \\
\hline
\end{tabular}

DLM, Tithonia diversifolia leaf meal.

Means with the same superscripts in the same row are not significantly different $(p>0.05)$

Table 2: Slaughter traits of pigs fed varying levels of TDLM based diets

\begin{tabular}{|lcccc|}
\hline & \multicolumn{5}{c|}{ Diets } \\
\hline & $\mathbf{1}$ & $\mathbf{2}$ & $\mathbf{3}$ & $\mathbf{4}$ \\
\hline & $\mathbf{0}$ & $\mathbf{0}$ inclusion levels of TDLM & \\
\hline Parameters & $20.2^{\mathrm{a}} \pm 3.21$ & $15.6^{\mathrm{b}} \pm 3.42$ & $14.4^{\mathrm{b}} \pm 2.31$ & $13.9^{\mathrm{b}} \pm 3.43$ \\
Live weight at slaughter $(\mathrm{kg})$ & $14.6^{\mathrm{a}} \pm 2.31$ & $11.5^{\mathrm{b}} \pm 3.01$ & $9.6^{\mathrm{c}} \pm 3.41$ & $9.6^{\mathrm{c}} \pm 3.23$ \\
Empty slaughter weight $(\mathrm{kg})$ & $4.5^{\mathrm{a}} \pm 3.42$ & $3.5^{\mathrm{a}} \pm 3.23$ & $4.5^{\mathrm{a}} \pm 3.51$ & $4.4^{\mathrm{a}} \pm 3.31$ \\
Weight of intestine with offal $(\mathrm{kg})$ & $1.1^{\mathrm{a}} \pm 3.01$ & $0.6^{\mathrm{a}} \pm 2.42$ & $0.7^{\mathrm{a}} \pm 3.24$ & $0.6^{\mathrm{a}} \pm 3.01$ \\
Blood weight $(\mathrm{kg})$ & $0.4^{\mathrm{a}} \pm 3.21$ & $0.3^{\mathrm{b}} \pm 3.54$ & $0.3^{\mathrm{b}} \pm 3.02$ & $0.3^{\mathrm{b}} \pm 3.01$ \\
Body mass index & $19.1^{\mathrm{a}} \pm 3.01$ & $15.1^{\mathrm{b}} \pm 2.20$ & $13.9^{\mathrm{b}} \pm 2.10$ & $13.5^{\mathrm{b}} \pm 2.00$ \\
Dead weight $(\mathrm{kg})$ & $0.9^{\mathrm{a}} \pm 1.01$ & $0.5^{\mathrm{b}} \pm 0.54$ & $0.5^{\mathrm{b}} \pm 0.91$ & $0.3^{\mathrm{c}} \pm 0.78$ \\
Back fat depth $(\mathrm{cm})$ & & & & \\
\hline
\end{tabular}

TDLM, Tithonia diversifolia leaf meal.

Means with the same superscripts in the same row are not significantly different $(p>0.05)$ 


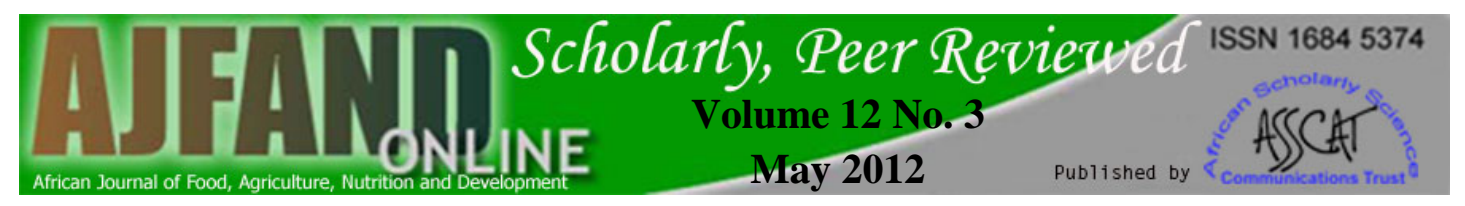

Table 3: Offals and organs yields of pigs fed varying levels of TDLM based diets

\begin{tabular}{|c|c|c|c|c|}
\hline & \multicolumn{4}{|c|}{ Diets } \\
\hline & 1 & 2 & 3 & 4 \\
\hline & \multicolumn{4}{|c|}{$\%$ inclusion levels of TDLM } \\
\hline Parameters & $\mathbf{0}$ & 10 & 20 & 30 \\
\hline \multicolumn{5}{|l|}{ Weight } \\
\hline Head (kg) & $2.4^{\mathrm{a}} \pm 2.01$ & $2.0^{\mathrm{ab}} \pm 2.21$ & $1.5^{b} \pm 2.03$ & $1.8^{\mathrm{ab}} \pm 1.94$ \\
\hline Feet from knee (kg) & $0.9^{\mathrm{a}} \pm 2.31$ & $0.6^{\mathrm{a}} \pm 1.90$ & $0.7^{\mathrm{a}} \pm 0.98$ & $0.5^{\mathrm{a}} \pm 1.01$ \\
\hline Spleen (g) & $25.1^{\mathrm{a}} \pm 0.04$ & $19.1^{\mathrm{b}} \pm 0.34$ & $13.2^{\mathrm{C}} \pm 0.31$ & $17.2^{\mathrm{d}} \pm 0.32$ \\
\hline Lungs (g) & $194.6^{\mathrm{a}} \pm 0.78$ & $45.6^{\mathrm{b}} \pm 0.98$ & $67.7^{\mathrm{C}} \pm 0.72$ & $171.7^{\mathrm{d}} \pm 0.49$ \\
\hline Heart (g) & $68.6^{\mathrm{a}} \pm 0.34$ & $59.6^{\mathrm{b}} \pm 0.76$ & $57.7^{\mathrm{b}} \pm 0.87$ & $61.7^{\mathrm{b}} \pm 0.97$ \\
\hline Stomach (g) & $647.6^{\mathrm{a}} \pm 0.67$ & $482.6^{\mathrm{b}} \pm 0.76$ & $633.7^{c} \pm 0.45$ & $539.7^{\mathrm{d}} \pm 0.76$ \\
\hline Intestine (kg) & $2.7^{\mathrm{a}} \pm 0.76$ & $2.4^{\mathrm{a}} \pm 0.75$ & $2.7^{\mathrm{a}} \pm 0.56$ & $2.4^{\mathrm{a}} \pm 0.75$ \\
\hline Liver (g) & $616.8^{a} \pm 0.54$ & $386.0^{\mathrm{b}} \pm 0.56$ & $368.0^{c} \pm 0.84$ & $310.5^{d} \pm 0.53$ \\
\hline Kidney (g) & $64.8^{\mathrm{a}} \pm 0.52$ & $44.1^{b} \pm 0.43$ & $52.0^{c} \pm 0.24$ & $50.2^{\mathrm{C}} \pm 0.34$ \\
\hline Bile (g) & $37.6^{\mathrm{a}} \pm 0.21$ & $13.0^{\mathrm{b}} \pm 0.42$ & $11.1^{\mathrm{b}} \pm 0.32$ & $12.2^{\mathrm{b}} \pm 0.43$ \\
\hline Testes (g) & $52.6^{\mathrm{a}} \pm 0.32$ & $50.7^{\mathrm{a}} \pm 0.41$ & $49.7^{\mathrm{a}} \pm 0.24$ & $48.8^{\mathrm{a}} \pm 0.31$ \\
\hline \multicolumn{5}{|l|}{ Length } \\
\hline Front leg (cm) & $15.1^{\mathrm{a}} \pm 0.24$ & $13.1^{\mathrm{a}} \pm 0.31$ & $15.1^{\mathrm{a}} \pm 0.34$ & $13.2^{\mathrm{b}} \pm 0.32$ \\
\hline Back leg $(\mathrm{cm})$ & $20.1^{\mathrm{a}} \pm 0.41$ & $18.1^{\mathrm{b}} \pm 0.52$ & $19.1^{\mathrm{a}} \pm 0.32$ & $18.2^{\mathrm{b}} \pm 0.31$ \\
\hline
\end{tabular}

TDLM, Tithonia diversifolia leaf meal

Means with the same superscripts in the same row are not significantly different $(p>0.05)$

Table 4: Primal cut yield of pigs fed varying levels of TDLM based diets

\begin{tabular}{|lcccc|}
\hline \multicolumn{5}{c}{ Diets } \\
\hline & $\mathbf{1}$ & $\mathbf{2}$ & $\mathbf{3}$ & $\mathbf{4}$ \\
\hline Parameters & $\mathbf{0}$ & $\mathbf{1 0}$ & $\mathbf{\%}$ inclusion levels of TDLM \\
\hline Half cut $(\mathrm{kg})$ & $6.1^{\mathrm{a}} \pm 2.01$ & $4.7^{\mathrm{a}} \pm 2.11$ & $4.1^{\mathrm{b}} \pm 2.01$ & $3.6^{\mathrm{b}} \pm 2.31$ \\
Quarter cut $(\mathrm{kg})$ & $3.2^{\mathrm{a}} \pm 2.00$ & $2.5^{\mathrm{a}} \pm 2.01$ & $2.1^{\mathrm{a}} \pm 1.32$ & $2.1^{\mathrm{a}} \pm 2.01$ \\
Shoulder weight $(\mathrm{kg})$ & $3.4^{\mathrm{a}} \pm 2.31$ & $3.0^{\mathrm{a}} \pm 2.01$ & $2.5^{\mathrm{a}} \pm 2.41$ & $2.4^{\mathrm{a}} \pm 2.21$ \\
Bacon weight $(\mathrm{kg})$ & $1.5^{\mathrm{a}} \pm 2.21$ & $1.0^{\mathrm{a}} \pm 2.11$ & $0.9^{\mathrm{a}} \pm 2.01$ & $0.8^{\mathrm{a}} \pm 2.11$ \\
Ham weight $(\mathrm{kg})$ & $3.7^{\mathrm{a}} \pm 3.01$ & $3.1^{\mathrm{a}} \pm 2.01$ & $2.5^{\mathrm{a}} \pm 2.01$ & $2.4^{\mathrm{a}} \pm 2.11$ \\
Ribs weight $(\mathrm{kg})$ & $2.9^{\mathrm{a}} \pm 2.01$ & $2.4^{\mathrm{a}} \pm 3.21$ & $2.0^{\mathrm{a}} \pm 2.21$ & $2.1^{\mathrm{a}} \pm 3.01$ \\
Loin eye weight $(\mathrm{kg})$ & $0.8^{\mathrm{a}} \pm 3.12$ & $0.7^{\mathrm{a}} \pm 2.41$ & $0.7^{\mathrm{a}} \pm 2.01$ & $0.8^{\mathrm{a}} \pm 2.31$ \\
& & & & \\
\hline
\end{tabular}

TDLM, Tithonia diversifolia leaf meal

Means with the same superscripts in the same row are not significantly different $(p>0.05)$ 


\section{REFERENCES}

1. Sung WK Bio-fermentation technology to improve efficiency of swine nutrition. Asian-Australasian Journal of Animal Science. 2010; 23(6): 825832. www.ajas.info (Accessed January 15, 2011).

2. Wang TC and MF Fuller The optimum dietary amino acid pattern for growing pigs. British Journal of Nutrition. 1989; 62:17-89.

3. Speer VC Partitioning nitrogen and amino acid for pregnancy and lactation in swine. A review: Journal of Animal science, 1990; 68:553-561.

4. Ayeni AO, Lordbanjou DT and BA Majek Tithonia diversifolia (Mexican sunflower) in South-Western Nigeria: Occurrence and growth habit. Weed Research (Oxford) 1997; 37:443-449.

5. Akinola JO, Larbi A, Farinu GO and AA Odunsi Seed treatment methods and duration effects on germination of wild sunflower. Expl. Agric., 1999; 36:63-69.

6. Togun VA, Farinu GO, Ojebiyi OO, Akinlade JA and OB Popoola Evaluation of Three Dietary Levels of Wild Sunflower (Tithonia diversifolia, Hemsi A.Grey) Forage Meal on Growth and Carcass Measurement of Male Rabbits. Journal of Animal and Veterinary Advances 2006; 5(10):791 - 794.

7. Fasuyi AO, Dairo FAS and FJ Ibitayo Physicochemical analyses of ensiled wild sunflower (Tithonia diversifolia) leaves with sugar cane molasses silage additive. Livestock Research for Rural Development 22(03)2010. http://www.cipav.org.co/lrrd/lrrd21/12/rodr18091.htm (Accessed January 15, 2011).

8. USDA. Slaughtering, cutting and processing of pork on the farm. Farmers' Bulletin 1970; No. 2138 United States Department of Agriculture.

9. Okubanjo AO Physical and Organoleptic Characteristics of Leg-twisted Beef Carcass. Journal of Food Science and Technology. 1985; 22:365-368.

10. Bamgbose AM and AT Niba Performance of broiler chicken fed cotton seed cake in starter and finisher rations. In Ologhobo A.D. and Iyayi, E.A. (Editors). The Nigerian livestock in the $21^{\text {st }}$ century. Proceedings of $3^{\text {rd }}$ annual conference of Animal Science Association of Nigeria September 22-24 1998, Lagos pp 84-87.

11. Sikka SS Comparative utilization of nutrients in poultry and swine. $1990 \mathrm{PhD}$. Dissertation in the Department of Animal Science submitted to Punjab Agricultural University, Ludhiana.

12. Sikka SS Effect of replacement of maize and rice bran with paddy on the growth performance and carcass traits of growing finishing pigs. Livestock Research for Rural Development 19 (7) 2008.

http://www.cipav.org.co/lrrd19/7/sikk19092.htm (Accessed January 15, 2011) 
13. Sikka SS Effect of incorporating biogas slurry (BGS) on the growth performance and carcass traits of growing pigs. Livestock Research for Rural Development 19 (7) 2008. http://www.cipav.org.co/lrrd18/5/sikk18070.htm (Accessed January 15, 2011).

14. Sikka SS, Chawla JS and JS Icchponani Effect of feeding ground spent coffee on the growth and carcass quality of pigs. Indian Journal of Animal Nutrition, 1985; 2(1):49-52.

15. Sikka SS and JS Chawla Effect of feeding spent coffee grounds on the feedlot performance and carcass quality of fattening pigs. Agricultural Wastes 1986; 18:305-308.

16. Dutta P, Bharatacharyya PR, Rabha IC, Bordolon ON, Barna NC, Chowdurry PK, Enujiugha VN and JO Agbede Nutritional and antinutritional characteristics of African oil bean (Pentaclethra macrophylla Benth) Seeds. Applied Tropical Agriculture 2000; 5:11-14.

17. Uchegbu MC, Okoli IC, Anyanwu CE, Etuk EB, Esonu BO and ABI Udedibie Performance, Carcass and organ characteristics of finisher broilers fed graded levels of raw Napoleona imperiahis seed meal. Livestock Research for Rural Development 2004; 16(6).

18. Togun VA, Farinu GO and RO Olabanji Feeding graded levels of wild sunflower (Tithonia diversifolia Hemsl. A. Gray) meal in replacement of maize at pre-pubertal age, negatively impacts on growth and morphometric characteristics of the genitalia of Anak 2000 Broiler Cocks at their pubertal Age. Nigeria World Applied Sciences Journal 2006; 1(2):115-118.

19. Togun VA, Farinu GO and RO Olabanji Effect of graded levels of wild sunflower (Tithonia diversifolia Hemsl A.Gray) meal in prepubertal diets on the morphometric characteristics of the genitalia and some organs of Isabrown cocks at the pubertal Age. American Eurasian Journal of Scientific Research 2006; 1(1):61-67.

20. Galmessa U, Raina VS, Mohanty TK and AK Gupta Seminal attributes related to age and scrotal circumference in dairy bulls. Indian Journal of Dairy Science, 2003; 56: 376-379.

21. Gupta AK and TK Mohanty Testicular biometry and semen quality in Karan-fries bulls. Indian Journal of Dairy Science, 2003; 56:317-319

22. Salem I, Salem AA and G Aboulwafa Relationship of testicular measurements to seasonal variation and level of feeding in Saidi rain lambs. Assiut. Veterinary Medicine Journal 2005; 51:29-39. 